\title{
Improvement of Learning Outcomes in Pkn Learning Through Problem Based Learning Model with Audio Visual Media Class IV Students SD Negeri 41 Sabangko
}

\author{
Haslinda \\ Universitas Sebelas Maret \\ Haslindaabbas828@gmail.com
}

\section{Article History}

accepted 14/11/2020

\begin{abstract}
Teachers still teach more and pursue targets that are oriented towards final exam scores. This relates to the formation of character, morals, attitudes and behavior of students who only want good values without being balanced with improvements in the character, morals, attitudes and behavior of the child. To improve the learning outcomes of Civics learning through the Problem Based Learning model using audiovisual media for grade IV SDN 41 Sabangko. This type of research is Classroom Action Research (PTK) through three learning cycles with data collection techniques, namely tests, observations, field notes, documentation, questionnaires and interviews. Data analysis, namely qualitative and quantitative analysis. The results showed that the three cycles carried out showed different values and the third cycle obtained better results so that the established hypothesis could be accepted as true, namely through problem-based learning with audiovisuals it could improve teacher skills, student activity, and student learning outcomes.
\end{abstract}

Keywords: teachers, students, pkn learning, audiovisual, learning outcomes

\begin{abstract}
Abstrak
Guru masih mengajar lebih banyak mengejar target yang berorientasi pada nilai ujian akhir. Hal ini berkaitan pada pembentukan karakter, moral, sikap serta perilaku murid yang hanya menginginkan nilai yang baik tanpa diimbangi dengan perbaikan karakter, moral, sikap serta perilaku dari anak tersebut. Untuk meningkatkan hasil belajar pembelajaran PKn melalui model Problem Based Learning dengan menggunakan media audiovisual pada siswa kelas IV SDN 41 Sabangko. Jenis penelitian adalah Penelitian Tidakan Kelas (PTK) melalui tiga siklus pembelajaran dengan teknik pengumpulan data yaitu tes, observasi, catatan lapangan, dokumentasi, angket dan wawancara. Analisis data yaitu analisis kualitatif dan kuantitatif. Hasil penelitian menunjukkan bahwa tiga siklus yang dilakukan menunjukkan nilai yang berrbeda dan siklus ke tiga memperoleh hasil yang lebih baik sehingga hipotesis yang telah ditetapkan dapat diterima kebenarannya yaitu melalui problem based learning dengan audiovisual dapat meningkatkan keterampilan guru, aktivitas siswa, dan hasil belajar siswa.
\end{abstract}

Kata kunci: guru, siswa, pembelajaran pkn, audiovisual, hasil belajar

Social, Humanities, and Education Studies (SHEs): Conference Series https://jurnal.uns.ac.id/shes

p-ISSN 2620-9284

e-ISSN 2620-9292 


\section{PENDAHULUAN}

Pendidikan Kewarganegaraan merupakan mata pelajaran wajib pada semua satuan pendidikan dasar dan pendidikan menengah. Aspek-aspek yang menjadi lingkup mata pelajaran ini, mencakup persatuan dan kesatuan bangsa, norma hukum dan peraturan, hak asasi manusia, kebutuhan warga negara, kekuasaan dan politik, pancasila, dan globalisasi (Depdiknas, 2007). Model problem based learning merupakan suatu model pembelajaran yang memotivasi para siswa untuk mendorong dan membantu satu sama lain untuk menguasai keterampilan-keterampilan yang disajikan oleh guru. Menurut Duch (1995) problem based learning adalah salah satu tipe atau model pembelajaran yang bercirikan adanya permasalahan nyata sebagai konteks untuk para peserta didik belajar, berpikir kritis dan keterampilan memecahkan masalah serta memproleh pengetahuan. Berdasarkan hasil temuan kajian kurikulum (dalam Depdiknas, 2007) menunjukkan bahwa terdapat ketidak seimbangan ranah kompetensi PKn sebagai muatan KD untuk setiap SK baik di SD, SMP, maupun SMA. Pada tiga jenis pendidikan ini, aspek sikap dan perilaku yang menjadi dasar utama pengajaran PKn proporsinya relatif lebih sedikit bila dibandingkan dengan ranah pengetahuan. Untuk SD dari $57 \mathrm{KD}$, hanya $4(7,02 \%) \mathrm{KD}$ yang termasuk ranah afeksi dan hanya $16(28,07 \%)$ KD yang termasuk ranah perilaku, sementara yang termasuk ranah pengetahuan $37(64,91 \%)$ KD. Selain itu, pembelajaran PKn juga cenderung kurang bermakna karena hanya berpatokan pada penilaian aspek kognitif saja, tidak pada aspek afektif dan psikomotor. Guru masih mengajar lebih banyak mengejar target yang berorientasi pada nilai ujian akhir. Hal ini berkaitan pada pembentukan karakter, moral, sikap serta perilaku murid yang hanya menginginkan nilai yang baik tanpa diimbangi dengan perbaikan karakter, moral, sikap serta perilaku dari anak tersebut. Permasalahan tersebut juga terjadi pada pembelajaran PKn di SDN Sabangko, hal tersebut ditemui peneliti dari hasil observasi terhadap guru, siswa, dan media atau alat pembelajaran. Selain itu, juga diperoleh dari hasil wawancara dan catatan lapangan.

Berdasarkan refleksi awal ditemui data sebagai berikut. Dari faktor guru yaitu, pembelajaran yang dilaksanakan seringkali hanya menggunakan metode yang berpusat pada guru dan tidak melibatkan aktivitas seluruh siswa. Sedangkan dari faktor siswa yaitu, siswa belum termotivasi untuk memperhatikan pembelajaran yang sedang berlangsung. Sedangkan dari factor media yaitu, guru belum optimal menggunakan media seperti internet, video ataupun gambar. Dari berbagai permasalahan yang terjadi menyebabkan hasil belajar PKn siswa kelas IV SDN 41 Sabangko kurang maksimal. Permasalahan di atas diperkuat dengan adanya data kuantitatif berupa hasil evaluasi pembelajaran PKn yang dilakukan sebanyak tiga kali. Dari hasil evaluasi tersebut diperoleh data bahwa sebagian besar siswa kelas IV SDN 41 Sabangko belum mencapai nilai diatas Kriteria Ketuntasan Minimal (KKM) yaitu sebesar 68. Dari 6 siswa kelas IV , hanya 2 siswa yang mendapat nilai diatas Kriteria Ketuntasan Minimal (KKM), sedangkan sisanya 4 siswa nilainya masih di bawah Kriteria Ketuntasan Minimal (KKM). Dengan nilai tertinggi sebesar 80 dan nilai terendah 50. Dari berbagai permasalahan yang muncul pada pembelajaran PKn di kelas IV SDN 41 Sabangko dan mengakibatkan keterampilan guru, aktivitas siswa, serta hasil belajar PKn menjadi kurang maksimal, sehingga perlu adanya perbaikan hasil belajar pembelajaran.

Berdasarkan latar belakang masalah di atas, peneliti melaksanakan Penelitian Tindakan Kelas (PTK) dengan judul "Peningkatan hasil belajar pada Pembelajaran PKn melalui Model Problem Based Learning dengan Media Audiovisual Siswa Kelas IV SDN 41 Sabangko".

\section{METODE}

Penelitian tindakan kelas ini dilaksanakan di SDN 41 Sabangko yang berlokasi di Pulau Sabangko, Desa Mattiro Bombang, Kec. Liukang Tupabbiring Utara, Kabupaten 
Pangkajene Kepulauan Provinsi Sulawesi Selatan Tahun pelajaran 2020/2021. Penelitian ini dilaksanakan pada semester I tahun pelajaran 2020/2021 dimulai dari bulan Oktober sampai bulan November 2020. Subjek dari penelitian ini adalah peserta didik kelas IV Sekolah Dasar Negeri 41 Sabangko, dengan jumlah peserta didik dalam satu kelas sebanyak 6 siswa yang terdiri dari 2 siswa laki-laki dan 4 siswa perempuan., dengan fokus penelitian pada peningkatan hasil belajar pada peserta didik kelas IV SDN 41 Sabangko. Jenis penelitian yang digunakan adalah PTK (penelitian tindakan kelasKegiatan penelitian ini dilaksanakan melalui 3 siklus pembelajaran yang terdiri dari siklus awal atau prasiklus sebagai dasar mengetahui sejauh mana prestasi belajar yang dimiliki oleh peserta didik kelas IV. Siklus selanjutnya merupakan langkah pembelajaran yang diambil sebagai tindakan atau langkah perbaikan yang disebut siklus 1 siklus 2 dan siklus 3 . Pengumpulan data dalam penelitian menggunakan beberapa teknik, yaitu tes, observasi, catatan lapangan, dokumentasi, angket dan wawancara. Data yang dikumpulkan dianalisis dengan menggunakan analisis kuantitatif dan analisis kualitatif

\section{HASIL DAN PEMBAHASAN}

Tindakan perbaikan pembelajaran pada siklus I, II, III telah dilaksanakan dengan pemberian evaluasi pada akhir siklus berupa tes formatif. Sasaran yang ingin dicapai pada evaluasi ini yaitu untuk mengetahui tingkat kemampuan siswa terhadap materi yang diajarkan serta mengukur tingkat keberhasilan siswa dalam aspek pemahaman tentang pengamalan nilai- nilai pancasila dalam dalam kehidupan seharihari dengan penggunaan media audio visual.

Tabel 1 Rekapitulasi Nilai Pengetahuan Pembelajaran Siklus I

\begin{tabular}{cccccccc}
\hline & & & \multicolumn{5}{c}{ Siklus I } \\
No & Nama Siswa & $\begin{array}{c}\text { Studi } \\
\text { Awal }\end{array}$ & Nilai & Naik & $\begin{array}{c}\text { Belum } \\
\text { Naik }\end{array}$ & $\begin{array}{c}\text { Ketuntasan } \\
\text { T }\end{array}$ & B \\
\hline 1 & Aspar & 50 & 50 & - & $\sqrt{ }$ & - & B \\
2 & Fitri Ramadhani & 60 & 65 & $\sqrt{ }$ & - & - & B \\
3 & Firman & 60 & 75 & $\sqrt{ }$ & - & T & - \\
4 & Kartiah & 80 & 85 & $\sqrt{ }$ & - & T & - \\
5 & Putri Aulia & 80 & 90 & $\sqrt{ }$ & - & T & - \\
6 & Nur Halizah & 50 & 60 & $\sqrt{ }$ & - & - & B \\
& Jumlah & $\mathbf{3 8 0}$ & $\mathbf{4 2 5}$ & $\mathbf{5}$ & $\mathbf{1}$ & $\mathbf{3}$ & $\mathbf{3}$ \\
& $\quad$ Rata-Rata & $\mathbf{6 3 , 3}$ & $\mathbf{7 0 , 8}$ & - & - & - & - \\
& Prosentase & - & - & $\mathbf{8 3 , 3 \%}$ & $\mathbf{1 6 , 7 \%}$ & $\mathbf{5 0 \%}$ & $\mathbf{5 0 \%}$
\end{tabular}

Tabel 2. Rekapitulasi Nilai Keterampilan Pembelajaran Siklus 2

\begin{tabular}{|c|c|c|c|c|c|c|c|c|}
\hline \multirow{3}{*}{ No } & \multirow{3}{*}{ Nama Siswa } & \multirow{3}{*}{$\begin{array}{c}\text { Stud } \\
\text { i } \\
\text { Awal }\end{array}$} & \multirow{3}{*}{$\underset{I}{\text { Siklus }}$} & \multicolumn{5}{|c|}{$\begin{array}{c}\text { Keterampilan PPKN Siklus II } \\
\text { (KKM 70) }\end{array}$} \\
\hline & & & & \multirow{2}{*}{ Nilai } & \multirow{2}{*}{ Naik } & \multirow{2}{*}{$\begin{array}{l}\text { Blm } \\
\text { Naik }\end{array}$} & \multicolumn{2}{|c|}{ Ketuntasan } \\
\hline & & & & & & & $\mathrm{T}$ & B \\
\hline \multirow{2}{*}{$\begin{array}{l}1 \\
2\end{array}$} & Aspar & 60 & 65 & \multirow{2}{*}{$\begin{array}{l}65 \\
75\end{array}$} & \multirow[b]{2}{*}{$\sqrt{ }$} & \multirow[t]{2}{*}{$\sqrt{ }$} & - & $B$ \\
\hline & $\begin{array}{l}\text { Fitri } \\
\text { Ramadhani }\end{array}$ & 65 & 65 & & & & $\mathrm{~T}$ & - \\
\hline 3 & Firman & 60 & 70 & 85 & $\sqrt{ }$ & - & $\mathrm{T}$ & - \\
\hline 4 & Kartiah & 80 & 85 & 90 & $\sqrt{ }$ & - & $\mathrm{T}$ & - \\
\hline
\end{tabular}


SHEs: Conference Series 3 (3) (2020) 902-907

\begin{tabular}{ccccccccc}
\hline 5 & Putri Aulia & 75 & 85 & 90 & $\sqrt{ }$ & - & $\mathrm{T}$ & - \\
6 & Nur Halizah & 60 & 65 & 75 & $\sqrt{ }$ & - & - & - \\
& Jumlah & $\mathbf{4 0 0}$ & $\mathbf{4 3 5}$ & $\mathbf{4 9 0}$ & $\mathbf{5}$ & $\mathbf{1}$ & $\mathbf{5}$ & $\mathbf{1}$ \\
& Rata-Rata & $\mathbf{6 6 , 7}$ & $\mathbf{7 2 , 5}$ & $\mathbf{8 1 , 7}$ & - & - & - & - \\
& Prosentase & - & & - & $\mathbf{8 3 \%}$ & $\mathbf{1 7 \%}$ & $\mathbf{8 3 \%}$ & $\mathbf{1 7 \%}$ \\
\hline
\end{tabular}

Tabel 3. Rekapitulasi Nilai Keterampilan Pembelajaran Siklus 3

\begin{tabular}{|c|c|c|c|c|c|c|c|c|c|}
\hline \multirow{3}{*}{ No } & \multirow{3}{*}{ Nama Siswa } & \multirow{3}{*}{$\begin{array}{l}\text { Studi } \\
\text { Awal }\end{array}$} & \multirow{3}{*}{$\underset{I}{\text { Siklus }}$} & \multirow{3}{*}{$\begin{array}{l}\text { Siklus } \\
\text { II }\end{array}$} & \multicolumn{5}{|c|}{$\begin{array}{l}\text { Keterampilan PPKN Siklus III } \\
\text { (KKM 68) }\end{array}$} \\
\hline & & & & & \multirow{2}{*}{ Nilai } & \multirow{2}{*}{ Naik } & \multirow{2}{*}{$\begin{array}{l}\text { Blm } \\
\text { Naik }\end{array}$} & \multicolumn{2}{|c|}{ Ketuntasan } \\
\hline & & & & & & & & $\mathrm{T}$ & B \\
\hline 1 & Aspar & 60 & 65 & 65 & 81 & $\sqrt{ }$ & - & $\mathrm{T}$ & - \\
\hline 2 & $\begin{array}{l}\text { Fitri } \\
\text { Ramadhani }\end{array}$ & 65 & 65 & 75 & 92 & $\sqrt{ }$ & - & $\mathrm{T}$ & - \\
\hline 3 & Firman & 60 & 70 & 85 & 95 & $\sqrt{ }$ & - & $\mathrm{T}$ & - \\
\hline 4 & Kartiah & 80 & 85 & 90 & 98 & $\sqrt{ }$ & - & $\mathrm{T}$ & - \\
\hline 5 & Putri Aulia & 75 & 85 & 90 & 97 & $\sqrt{ }$ & - & $\mathrm{T}$ & - \\
\hline 6 & Nur Halizah & 60 & 65 & 75 & 94 & $\sqrt{ }$ & - & $\mathrm{T}$ & - \\
\hline & Jumlah & 400 & 435 & 480 & 557 & 6 & - & 6 & - \\
\hline & Rata-Rata & 66,7 & 72,5 & 80,0 & 92,8 & - & - & - & - \\
\hline & Prosentase & - & & & - & $100 \%$ & $0 \%$ & $100 \%$ & $0 \%$ \\
\hline
\end{tabular}

\section{Siklus I}

Alternatif pemecahan masalah untuk mengatasi rendahnya keaktifan dan hasil belajar siswa terhadap konsep Pemahaman tentang nilai sila dalam Pancasila dengan menggunakan media audio visual pada siswa kelas IV SD Negeri 41 Sabangko, ternyata dapat meningkatkan hasil belajar dan pemahaman belajar siswa yang signifikan. Upaya yang dilakukan guru (peneliti) untuk memperbaiki pembelajaran ini sesuai dengan prinsip mengaktifkan siswa yang dikemukakan oleh Hernawan, dkk (2011:11.5) yaitu belajar merupakan suatu proses yang aktif yang melibatkan pancaindra atau fisik dan psikis kita. Agar siswa mengalami proses belajar, cara yang dapat dilakukan guru antara lain dengan menggunakan berbagai metode atau media pembelajaran yang tepat, yang dapat merangsang keterlibatan fisik dan psikis siswa.

Kegiatan pembelajaran pada siklus I ini belum mencapai batas kriteria keberhasilan yang telah ditetapkan. Dari 6 siswa, hanya 3 siswa $(50 \%)$ mencapai nilai tuntas, dengan nilai rata-rata kelas 70,8. Meskipun hasil pada siklus I belum sesuai target, perbaikan pembelajaran dengan media audio visual telah menujukkan peningkatan dibandingkan dengan sebelum tindakan perbaikan (pra siklus). Adapun ketidak berhasilan atau belum berhasilnya tindakan perbaikan pada siklus I tersebut disebabkan oleh beberapa faktor. Hasil refleksi menunjukkan bahwa belum berhasilnya tindakan pada siklus I antara lain disebabkan oleh faktor media yang tidak mencukupi, waktu yang kurang, partisipasi siswa yang kurang dalam kelompoknya. Untuk itu, guru mencoba mengupayakan perbaikan pembelajaran pada siklus II

\section{Siklus II}

Berdasarkan hasil refleksi pada siklus I, peneliti mengupayakan tindakan perbaikan pembelajaran pada siklus II yang diharapkan memberi kontribusi terhadap 
peningkatan hasil belajar siswa, yaitu terutama tentang Pembelajaran PKN. Masalah seperti ini dirancang agar siswa tertantang untuk menyelesaikan. Meskipun siswa pada awalnya mengalami kesulitan pemecahan masalah karena tidak ada aturan/prosedur yang segera dapat digunakan.

Setelah peneliti melaksanakan tindakan perbaikan pembelajaran pada pembelajaran Pemahaman tentang nilai sila dalam Pancasila dalam dua siklus, peneliti menemukan tiga hal penting yang menjadi acuan. Pertama, pada akhir siklus II sebagian besar siswa menyatakan bahwa tindakan perbaikan yang dilakukan dengan penggunaan media audio visual dapat membantu siswa mempermudah memahami materi pembelajaran. Kedua, pada akhir siklus II terjadi peningkatan hasil belajar terutama Pemahaman tentang nilai sila dalam Pancasila ketuntasan belajar menjadi $83 \%$ dari pra siklus yang hanya $33 \%$. Ketiga, terjadinya peningkatan terhadap pemahaman siswa dalam belajar yang dapat dilihat dalam lembar pengamatan.

Hasil refleksi menunjukkan bahwa belum berhasilnya tindakan pada siklus II antara lain disebabkan oleh faktor media yang tidak mencukupi, waktu yang kurang, partisipasi siswa yang kurang dalam kelompoknya. Untuk itu, guru mencoba mengupayakan perbaikan pembelajaran pada siklus III

\section{Siklus III}

Berdasarkan hasil refleksi pada siklus III, peneliti telah berhasil memenuhi nilai KKM hal ini disebabkan oleh tingkat percaya diri siswa yang telah meningkat sehingga proses pembelajaran berjalan efesien dan efektif sehingga mecapai nilai ketuntasan sesuai yang diharapkan.

\section{SIMPULAN}

Berdasarkan hasil analisis data pada bab IV dan pembahasan mengenai hasil belajar pembelajaran, yaitu keterampilan guru, aktivitas siswa, dan hasil belajar siswa pada pembelajaran PKn melalui problem based learning dengan audiovisual pada siswa kelas IV SDN 41 Sabangko dapat disimpulkan bahwa hasil belajar pembelajaran PKn meningkat 3 . Hasil belajar nilai pengetahuan dalam pembelajaran PKn melalui problem based learning dengan audiovisual pada siswa kelas IV SDN 41 Sabangko pada studi awal rata rata nilai sebesar 63,3 dan pada siklus I rata rata nilai pengetahuan siswa menjadi 70,8 , setelah dilakukan perbaikan pada siklus II nilai rata rata pengetahuan mengalami kenaikan menjadi 81,6 serta pada siklus III nilai rata rata pengetahuan lagi mengalami kenaikan menjadi 90,83.Dengan demikian dapat disimpulkan bahwa hipotesis yang telah ditetapkan dapat diterima kebenarannya yaitu melalui problem based learning dengan audiovisual dapat meningkatkan keterampilan guru, aktivitas siswa, dan hasil belajar siswa.

\section{DAFTAR PUSTAKA}

Arikunto, dkk. 2010. Penelitian Tindakan Kelas. Jakarta : PT Bumi Aksara. Aqip, Zainal. dkk. 2011. Penelitian Tindakan Kelas. Bandung: Yrama Widya Daryanto. 2010. Belajar dan Mengajar. Bandung : Yrama Widya . 2010. Media Pembelajaran. Yogyakarta: Gava Media Yogyakarta

Dr. M. Hosnan, Dipl.Ed., M.Pd. 2002. Pendekatan Saintifik dan Kontekstual dalam Pembelajaran Abad 21. Bogor: Ghalia Indonesia

Dr. Rusman, M.Pd. 2013. Belajar dan Pembelajaran Berbasis Komputer Mengembangkan Profesionalisme Abad 21. Bandung: Alfabeta

Depdiknas. 2006. Standar isi untuk satuan pedidikan dasar dan menengah. Jakarta: BSNP 
Direktorat Jenderal Pendidikan Tinggi. 2004. Peningkatan hasil belajar Pembelajaran. Jakarta: Depdiknas.2008. Penilaian KinerjaGuru. Jakarta: Direktur Tenaga Kependidikan Ditjen PMPTK

Gustaf, Asyirint. 2010. Langkah Cerdas Menjadi Guru Sejati Berprestasi. Yogyakarta: Bahtera Buku

Erviana, Nila, dkk. 2012. Peningkatan Belajar PKn Tentang Kebebasan Berorganisasi Melalui Model Problem Based Learning. Jurnal Universitas Sebelas Maret. Jurusan PGSD Volume 1 Nomor 4 Tahun 2013

Hamalik, Oemar. 2007. Kurikulum dan Pembelajaran. Jakarta: Bumi Aksara Hamdani. 2011. Strategi Belajar Mengajar. Bandung: Pustaka Setia

Hamruni, M.Si. Prof. Dr. 2009. Strategi dan Model-model Pembelajaran AktifMenyenangkan. Yogyakarta : Fakultas Tarbiyah UIN Sunan Kalijaga

Herrhyanto dan Hamid. 2008. Statistika Dasar. Jakarta: Universitas Terbuka

Herrhyanto, Nar dan Akib, Hamid. 2008. Statistika Dasar. Jakarta : Universitas Terbuka.

Huda, Miftahul. 2012. Cooperative Learning. Yogyakarta : Pustaka Pelajar. 2013. Model-Model Pengajaran dan Pembelajaran. Yogyakarta: Pustaka Pelajar

Kustandi dan Sutjipto. 2011. Media Pembelajaran Manual dan Digital. Bogor, Ghalia Indonesia.

Mimin Haryati, 2010. Model dan Teknik Penilaian Pada Tingkat Satuan Pendidikan. Jakarta: Gaung Persada Press.

Mulyasa. 2013. Menjadi Guru Profesional. Bandung: PT Remaja Rosdakarya

Poerwanti, dkk. 2008. Asesmen Pembelajaran SD. Jakarta : DirjeN Dikti Depdiknas.

Purwanto. 2010. Evaluasi Hasil Belajar. Yogyakarta: Pustaka Pelajar

Scholastika Mariani, dkk. 2014. The Effectiveness of Learning by PBL Assisted Mathematics Pop Up Book Against The Spatial Ability in Grade VIII on Geometry Subject Matter. International Journal of Education and Research. 2014. Vol 2(8). Semarang State University

Shereen Ahmed, dkk. 2014. Impact of Problem Based Learning on Acquiring 21 Century Skills Among Nursing Students (Comparative Study). International of Advanced Research. 2014. Vol 2(7), 770-783. Faculty of Nursing Helwan University

Shoimin, Malik. 2014. 68 Model Pembelajaran Inovatif dalam Kurikulum 2013. Yogyakarta: Ar-Ruzz Media

Siregar Eveline dan Nara Hartini. 2014. Teori Belajar dan Pembelajaran. Bogor: Ghalia Indonesia

Solihatin, Etin. 2012. Strategi Pembelajaran PPKN. Jakarta: Bumi Aksara

Subhan Sofhian dan Sahid Gatara. 2011. Pendidikan Kewarganegaraan (Civic Education). Bandung: Focusmedia.

Sukiman. 2012. Pengembangan Media Pembelajaran. Yogyakarta: Pustaka Insan Madani

Suyanti, Dwi Retno. 2010. Strategi Pembelajaran Kimia. Yogyakarta: Graha IImu

Trianto, S.Pd., M.Pd. 2007. Model Pembelajaran Terpadu dalam Teori dan Praktek. Jakarta: Prestasi Pustaka 